\title{
EKSPLORASI WARNA ALAM MENGGUNAKAN KULIT BATANG, AKAR, DAUN DAN BUAH DARI TANAMAN MANGROVE (RHIZOPORA STYLOSA) SEBAGAI PEWARNA BATIK DENGAN PENGGUNAAN FIKSATOR TAWAS, TUNJUNG DAN KAPUR
}

\author{
Bayu Wirawan D. S. ${ }^{1}$, Hazbi As Siddiqi ${ }^{2}$ \\ ${ }^{1}$ Dosen Program Studi Teknik Batik, Politeknik Pusmanu \\ ${ }^{2}$ Program Studi D3 Teknik Batik, Politeknik Pusmanu \\ Jalan Jenderal Sudirman 29 Pekalongan \\ Korespondensi: bayuwirawands@politeknikpusmanu.ac.id
}

\begin{abstract}
ABSTRAK
Tujuan penelitian adalah untuk mendapatkan warna alam yang lebih beragam dari tanaman mangrove sebagai upaya menghasilkan batik warna alam yang lebih beragam. Pada penelitian ini menggunakan bahan zat warna alam (kulit batang, daun, akar, dan buah) mangrove. Alat, cara, dan waktu perlakuan sama. Perbedaanya terletak pada fiksator yang digunakan yaitu tawas, kapur dan tunjung. Proses pewarnaan kulit batang, daun, akar dan buah mangrove (Rhizopora Stylosa) tanpa mordanting dengan fiksator tunjung, kapur dan tawas. Hasil warna yang ditimbulkan menggunakan bagian kulit batang mangrove dengan fiksator tunjung cenderung berwarna abu-abu tua, dengan fiksator kapur cenderung berwarna coklat susu, sedangkan fiksator tawas cenderung berwarna coklat muda. Hasil warna yang ditimbulkan menggunakan bagian akar mangrove dengan fiksator tunjung cenderung berwarna abu-abu kehijauan, dengan fiksator kapur cenderung berwarna coklat kemerahan, sedangkan fiksator tawas cenderung berwarna coklat muda. Hasil warna yang ditimbulkan menggunakan bagian daun mangrove dengan fiksator tunjung cenderung berwarna abu-abu kehijauan, dengan fiksator kapur cenderung berwarna pink, sedangkan fiksator tawas cenderung berwarna coklat muda. Hasil warna yang ditimbulkan menggunakan bagian buah mangrove dengan fiksator tunjung cenderung berwarna abu-abu kehijauan, dengan fiksator kapur cenderung berwarna coklat muda, sedangkan fiksator tawas cenderung berwarna coklat muda.
\end{abstract}

Kata Kunci : Batik, warna alam, mangrove, rhizopora stylosa

\section{PENDAHULUAN}

Batik merupakan warisan budaya bangsa Indonesia yang sudah diakui UNESCO pada tanggal 2 Oktober 2009 sebagai salah satu warisan tak benda bangsa Indonesia. Sebagai penerus kita mempunyai kewajiban untuk melestarikan dan mengembangkannya, sehingga dari produk seni dapat menjadi produk yang bernilai jual tinggi, dapat diterima masyarakat luas, dan dapat menciptakan lapangan kerja yang menjanjikan. (Rini. S, 2011).

Pada mulanya semua bahan pewarnaan batik dibuat dari bahan-bahan alami yang berasal dari lingkungan setempat. Bahan pewarnaan alami tersebut juga lazim 
digunakan untuk karya-karya seni lain di kepulauan Nusantara. Sumber bahan pewarna yang digunakan adalah bagian kulit kayu, buah, bunga dan akar suatu tanaman. Di awal abad ke- 20 warna sintetis/kimia mulai digunakan luas oleh pengrajin-pengrajin batik di Pekalongan. Teknik pewarnaan sintetis/kimia menggeser teknik pewarnaan alami karena proses pengerjaan jauh lebih mudah, dan warna yang dihasilkan lebih beragam. Media kain yang digunakan pada awalnya adalah kain katun, karena pada dasarnya warna-warna alami hanya dapat terserap sempurna pada bahan baku serat alami. (Rini. S, 2011).

Sejalan dengan konsep pembangunan berkelanjutan dan pemanfaatan produk ramah lingkungan, batik mulai memanfaatkan sumber sumber pewarna alami, bahkan serat alami yang berasal dari tumbuhan di Indonesia. Negeri ini menyediakan beragam jenis tumbuhan pewarna untuk makanan, minuman sampai kain. (Rini. S, 2011).

Penggunaan batik berbahan serat dan pewarna alami, merupakan pemanfaatan keanekaragaman hayati yang akan berdampak pada pelestarian keanekaragaman hayati dan pendapatan ekonomi masyarakat. (Rini. S, 2011).

Kota Pekalongan sebagai kota pesisir yang banyak ditemukan tanaman bakau/mangrove jenis Rhizopora Stylosa. Tanaman mangrove dapat digunakan sebagai bahan baku pewarna alami.

Tujuan penelitian adalah untuk mendapatkan warna alam yang lebih beragam dari tanaman mangrove sebagai upaya menghasilkan batik warna alam yang lebih beragam.

\section{TINJAUAN PUSTAKA}

\subsection{Pengertian Kain Batik}

Kain batik adalah kain dengan corak khas motif batik, yang dilakukan dengan cara menitik atau menetes dengan menggunakan lilin batik sebagai bahan perintang dan selanjutnya dilakukan proses pewarnaan sampai tahap penyelesaian yaitu pelepasan bahan perintang tadi dengan air dalam suhu panas.

Bahan untuk membatik meliputi, yang pertama yaitu mori/kain. Kain yang digunakan pada umumnya yaitu kain sutera alat tenun mesin, alat tenun bukan mesin dan kain katun (primissima), kedua yaitu lilin atau malam yang merupakan campuran dari lilin parafin, lilin tawon, gondorukem, mata kucing, lemak hewan, dan yang ketiga yaitu zat warna, ada zat warna alam, zat warna kimia/sintetis dan zat pembantu. (Soesanto, 1980).

\subsection{Zat Warna Alam}

Sumber pewarna alami adalah tumbuhan, binatang dan mikroorganisme (Aberoumand, 2011; Rymbai et al., 2011; Gupta et al., 2011 dalam Pujilestari, 2015). Zat pewarna alam lebih banyak terdapat pada tumbuhan. Untuk mengambil zat pewarna tersebut harus diekstrak/ fermentasi dari bagian tumbuhan yang mengandung zat warna paling banyak (daun, kayu, kulit kayu, akar, bunga, kulit buah, buah, biji atau kulit biji). 


\subsection{Mangrove (Rhizophora Stylosa) Sebagai Pewarna alam}

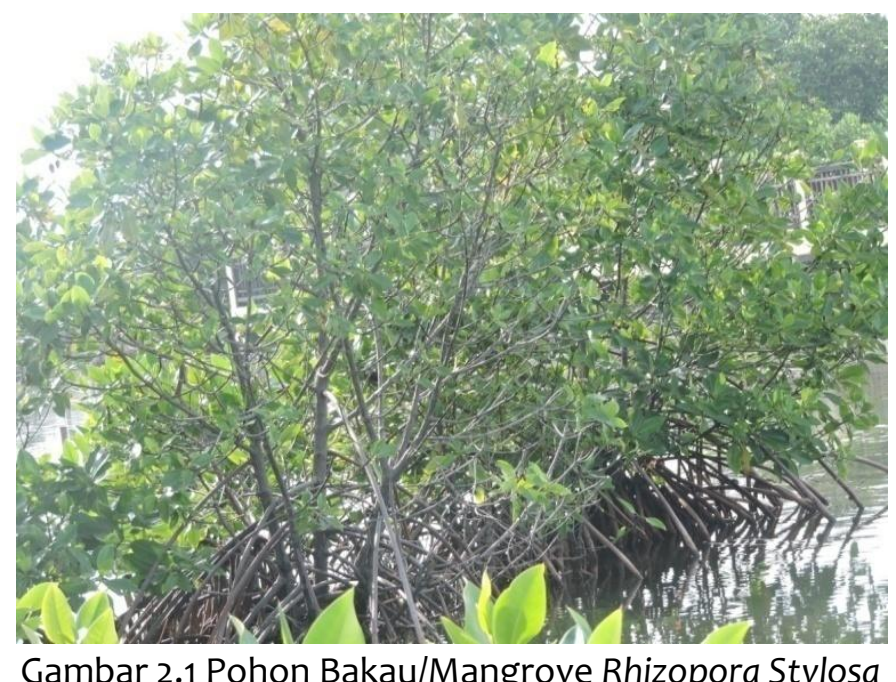

a. Klasifikasi

Divisi : Spermatophyta

Sub Divisi : Angiospermae

Kelas : Dicotiledonae

Sub Kelas : Dialypetalae

Ordo : Myrtales

Famili : Rhizophoraceae

Genus : Rhizophora

Spesies : Rhizophorasp.

b. Bagian yang digunakan

Bagian yang digunakan untuk proses pewarnaan adalah bagian kulit batang, daun, buah dan akar.

c. Kandungan Kimia

Hampir semua bagian tanaman Rhizopora Sp. (Rhizopora Stylosa) mengandung senyawa alkaloid, saponin, flavonoid, dan tanin. Alkaloid bersifat toksik terhadap mikroba, sehingga efektif membunuh bakteri dan virus. Tanin merupakan senyawa fenolik komplek yang dapat menghambat aktivitas bakteri sehingga tumbuhan yang mengandung tanin sering digunakan dalam bidang farmasi karena tanin mengandung asam tanik yang telah digunakan sebagai antiseptik. Dan selain itu tanin juga biasa dimanfaatkan sebagai bahan pewarna, perekat dan mordan, sehingga pada proses pewarnaan dengan menggunakan Bahan dasar mangrove bisa dilakukan tanpa menggunakan proses mordanting yang asalnya untuk memudahkan zat warna masuk dan mengikat ke serat kain.

\subsection{Ekstraksi}

Ekstraksi adalah proses pemisahan suatu bahan cair dari campurannya, penarikan keluar kandungan yang ada didalamnya. 


\subsection{Pembatikan}

Pelekatan lilin pada kain untuk membuat motif yang dikehendaki, dengan cara menuliskan canting tulis atau dengan cara dicap menggunakan canting cap. Agar dapat dituliskan atau dicapkan pada kain, maka lilin batik perlu dipanaskan dahulu pada suhu $\pm 60^{\circ}-70^{\circ} \mathrm{C}$ (Susanto, 1980).

Pembatikan dilakukan dengan canting tulis dan canting cap sesuai dengan corak motif yang diinginkan. Proses pembatikan dengan menggunakan lilin panas dengan hasil yang tidak mudah pecah tetapi mudah dilorod.

\subsection{Pewarnaan Kain Batik}

Syarat-syarat pokok zat warna dapat dipakai untuk pewarnaan adalah mudah larut dalam zat pelarutnya, mudah masuk kedalam bahan, stabil berada didalam serat. Pekerjaan pencelupan dilakukan berulang-ulang sampai dengan warna yang dikehendaki, semakin berulang hasil warna yang dihasilkan semakin matang.

\subsection{Fiksator}

Tujuan dilakukan fiksasi yaitu untuk mengunci zat warna alam golongan mordan serta berfungsi memberikan efek warna (arah warna) yang berbeda-beda sesuai dengan zat fiksasi yang digunakan (Sardjono, 2010).

Bahan fiksasi perlu dipilih dari bahan yang ramah lingkungan dan bersifat non-toksik supaya tidak menjadi masalah pada lingkungan (Kuniasari dan Maharani, 2015 dalam Pujilestari, 2015:8). Bahan pengikat yang sering digunakan antara lain : jeruk sitrun, jeruk nipis, cuka, sendawa, boraks, tawas, gula batu, gula jawa, gula aren, tunjung, prusi, tetes, air kapur, tape, pisang kluthuk, daun jambu kluthuk.

\subsection{Penghilangan Lilin}

Menurut Soesanto (1980), pekerjaan penghilangan lilin sebagian pada tempat-tempat tertentu dengan cara dikerok (ngerik) atau menghilangkan secara keseluruhan dengan cara "melorod" (disebut juga: nglorod, ngebyok dan mbabar). Bahan pembantu yang digunakan adalah kanji 5gr/l dengan temperatur mendidih.

\section{METODOLOGI PENELITIAN}

\subsection{Sumber data}

Metode yang digunakan adalah metode eksperimen. Metode eksperimen adalah suatu penelitian yang berusaha mencari pengaruh dari data primer diaplikasikan dengan data sekunder yang diperoleh dalam kondisi yang terkontrol. Objek penelitian ini menggunakan bahan pohon bakau/mangrove jenis Rhizopora Stylosa. Pada penelitian ini menggunakan bahan zat warna alam (kulit batang, daun, akar, dan buah) mangrove. Alat, cara, dan waktu perlakuan sama. Perbedaanya terletak pada fiksator yang digunakan yaitu tawas, kapur dan tunjung.

\subsection{Tahapan Penelitian}

Penelitian ini dilakukan dengan beberapa tahapan yaitu : 
1. Tahap persiapan eksperimen
a. Persiapan bahan kain
b. Pembuatan ekstrak mangrove (kulit batang, daun, akar dan buah)
c. Pembuatan larutan fiksasi

2. Tahap eksperimen
a. Pembatikan
b. Pewarnaan
C. Proses fiksasi
d. Pelorodan

\subsection{Kerangka Konseptual}

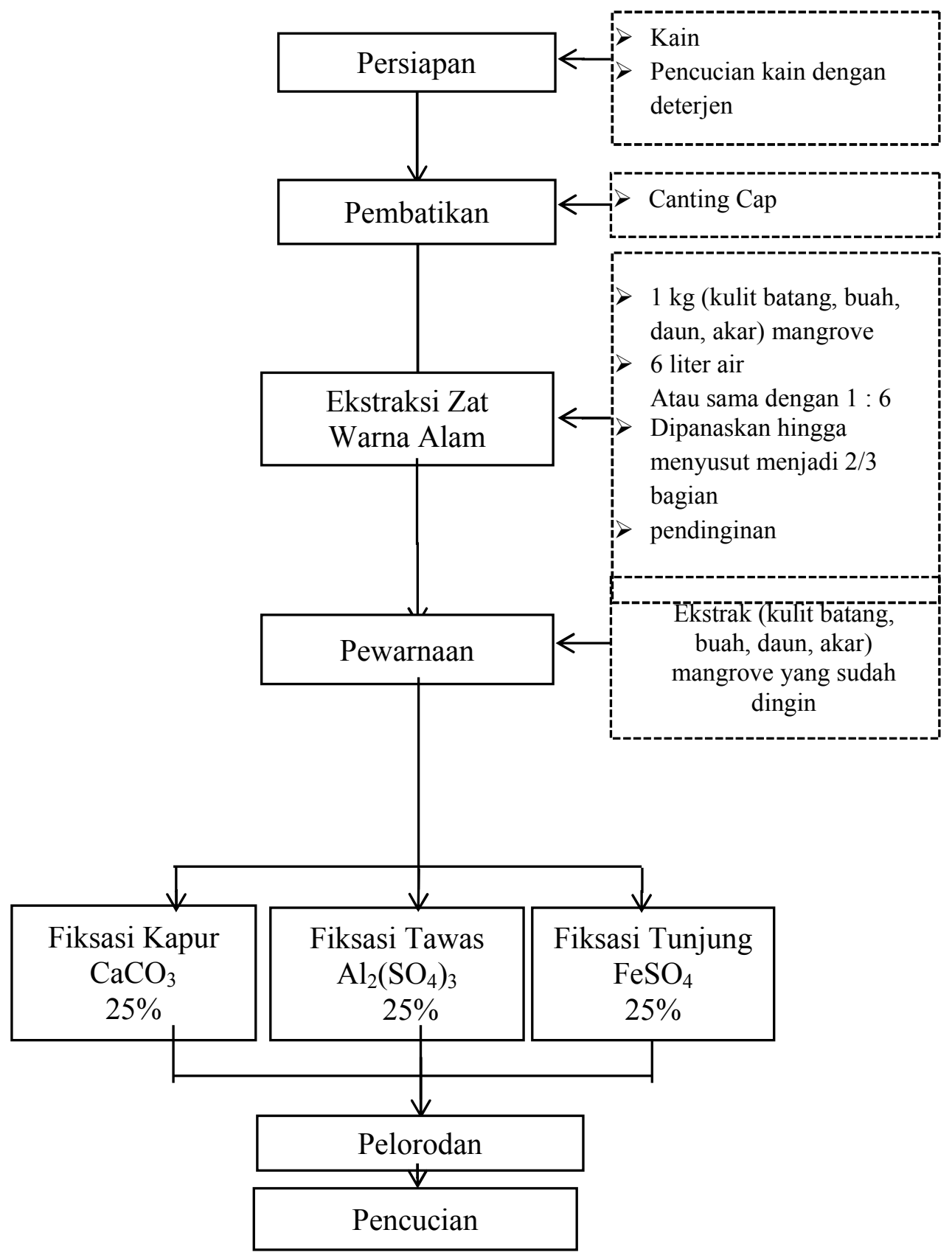

Gambar 3.1 Kerangka Konseptual Penelitian 


\section{HASIL DAN PEMBAHASAN}

4.1. Proses Pewarnaan Kain Batik dengan ekstrak mangrove (kulit batang, daun, akar, dan buah

4.1.1 Tahap persiapan eksperimen

1) Persiapan bahan kain

Persiapan bahan kain dengan mencuci kain katun primisima menggunakan deterjen yang fungsinya untuk menghilangkan debu atau sejenis minyak yang menempel pada kain yang dapat menghalangi proses pewarnaan.

2) Pembuatan ekstrak mangrove (kulit batang, akar, daun, dan buah)

Ekstrak kulit buah rambutan dibuat dengan perbandingan $1: 6$ yaitu $1 \mathrm{~kg}$ kulit buah rambutan dengan 6 liter air direbus dalam panci sampai mendidih hingga menyusut menjadi $2 / 3$ bagian. Setelah menyusut, api dimatikan. Saring ekstrak kulit buah rambutan, kemudian air hasil ekstraksi didinginkan, untuk selanjutnya digunakan mewarnai kain batik.
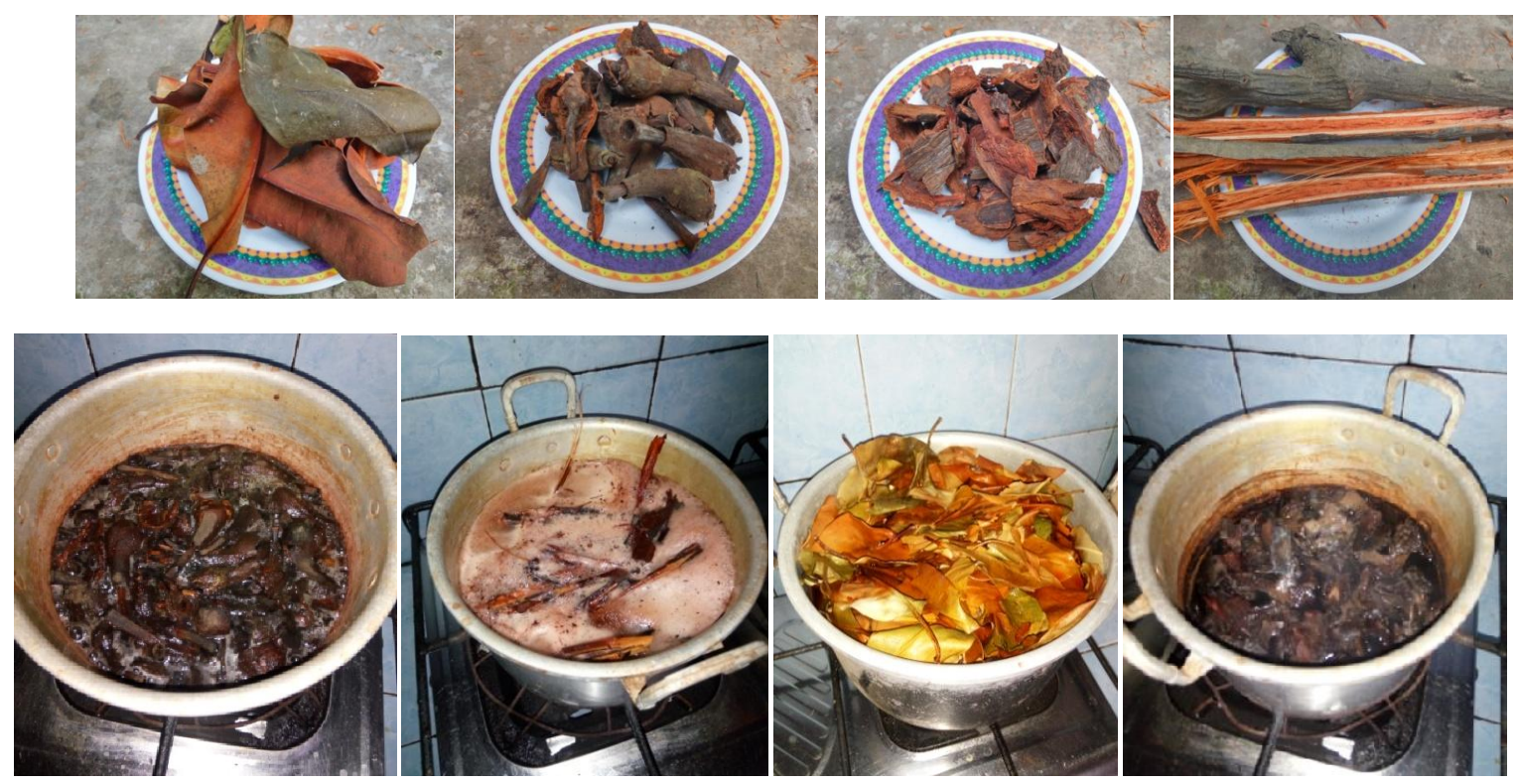

Gambar 4.1 Pembuatan ekstrak mangrove

3) Pembuatan larutan fiksasi

Larutan fiksasi dibuat dari larutan induk dengan konsentrasi $50 \mathrm{~g} / \mathrm{l}$, yaitu 50 gram zat fiksasi dalam 1 liter air. Sebagai variabel bebas yakni jenis dan konsentrasi fiksator antara lain kapur, tawas, dan tunjung sebesar $25 \%$ dari larutan induk. Larutan fiksasi konsentrasi $25 \%$ dibuat dengan cara mengambil $75 \mathrm{ml}$ larutan larutan induk ditambahkan dengan $225 \mathrm{ml}$ air. 


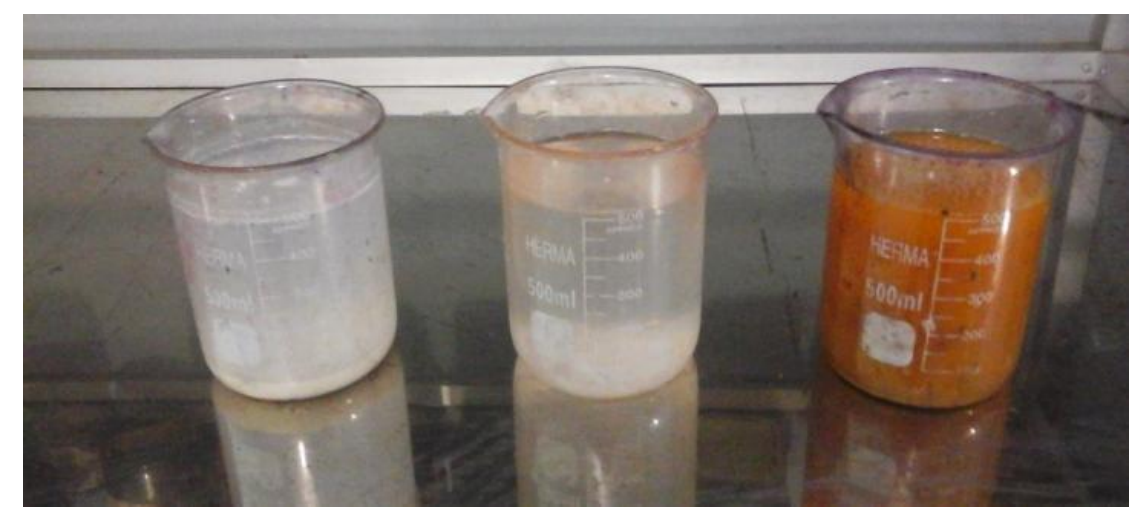

Gambar 4.2 Larutan Induk Fiksasi Kapur, Tawas, Tunjung

\subsubsection{Tahap eksperimen}

1) Pembatikan

Pembatikan dilakukan dengan cara pencapan yaitu menorehkan lilin batik pada kain putih dengan menggunakan canting cap.

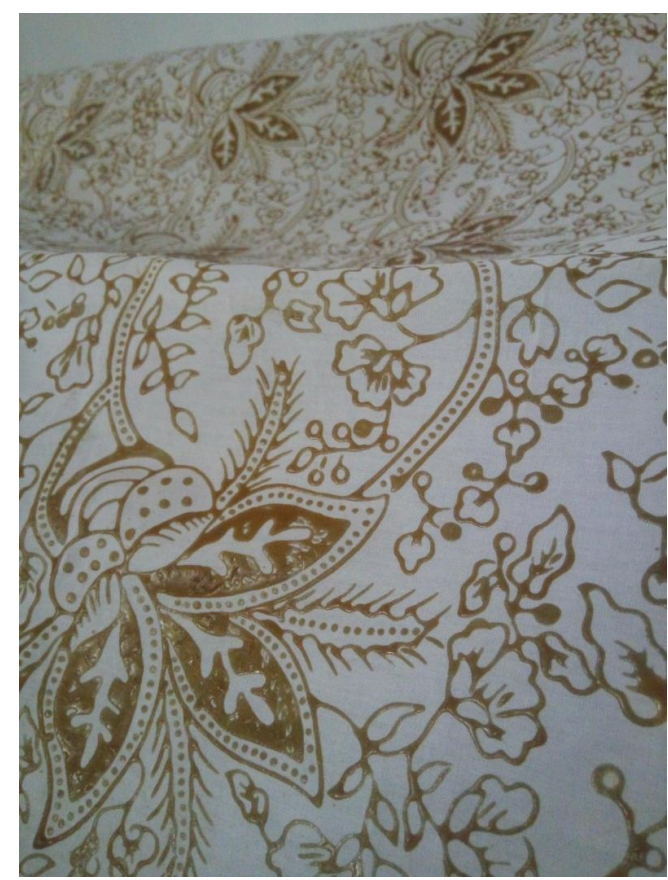

Gambar 4.3 Kain Hasil Pencapan

2) Pewarnaan

Proses pewarnaan dilakukan sebanyak 3 kali pengulangan.

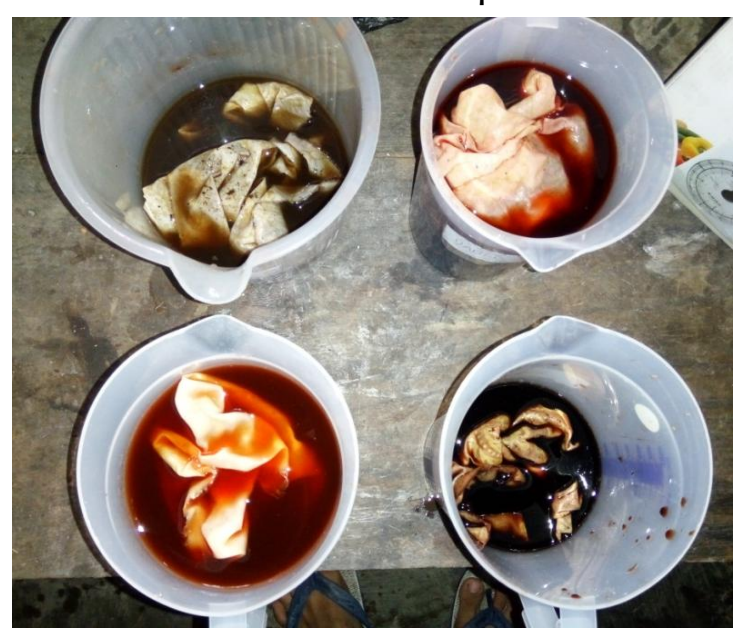

Gambar 4.4 Proses Pewarnaan

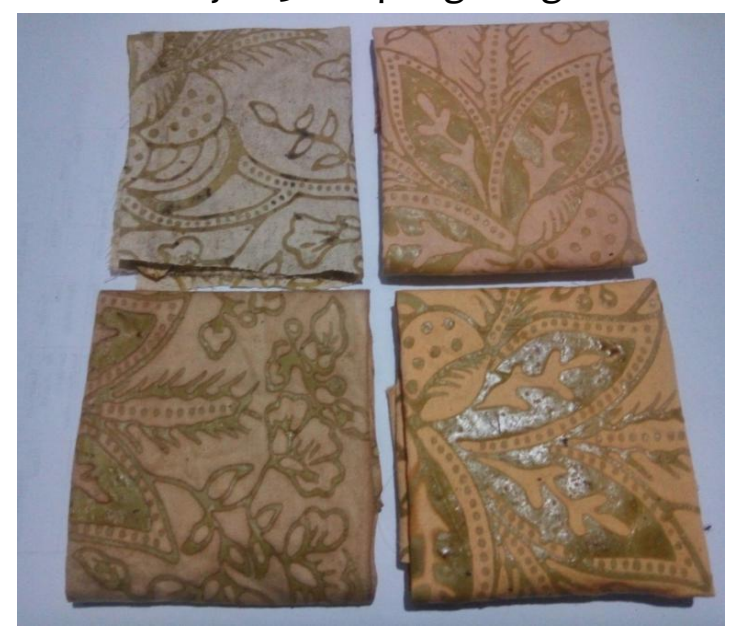

Gambar 4.5 Kain Hasil Pewarnaan 
3) Proses fiksasi

Sebelum proses fiksasi, contoh uji dipotong-potong menjadi 9 bagian. Selanjutnya, kain sampel dicelupkan ke dalam 9 larutan fiksasi dengan jenis dan konsentrasi fiksator yang sudah ditentukan (kapur 25\%, tawas $25 \%$, dan tunjung $25 \%$ )

4) Pelorodan

Proses pelepasan malam batik setelah proses fiksasi, dengan cara memasukan kain batik dalam air mendidih.

\subsection{Hasil Pewarnaan Kain Batik dengan ekstrak mangrove (kulit batang, akar, daun,} dan buah

Tabel 4.1 Perbandingan hasil pewarnaan kulit batang, akar, daun dan buah dengan fiksator tunjung, kapur dan tawas

\begin{tabular}{|c|c|c|c|c|}
\hline \multirow{2}{*}{ No. } & \multirow{2}{*}{$\begin{array}{c}\text { Bahan } \\
\text { Pewarna }\end{array}$} & \multicolumn{3}{|c|}{ Jenis Fiksator } \\
\hline & & Tunjung & Kapur & Tawas \\
\hline 1 & Kulit batang & & & \\
\hline 2 & Akar & & & \\
\hline 3 & Daun & & & \\
\hline 4 & Buah & & & \\
\hline & & & & \\
\hline & & & & \\
\hline
\end{tabular}

1. Hasil pewarnaan kain batik dengan ekstrak kulit batang mangrove

Hasil warna yang ditimbulkan menggunakan bagian kulit batang mangrove dengan fiksator tunjung cenderung berwarna abu-abu tua, dengan fiksator kapur cenderung berwarna coklat susu, sedangkan fiksator tawas cenderung berwarna coklat muda.

2. Hasil pewarnaan kain batik dengan ekstrak akar mangrove

Hasil warna yang ditimbulkan menggunakan bagian akar mangrove dengan fiksator tunjung cenderung berwarna abu-abu kehijauan, dengan fiksator kapur cenderung berwarna coklat kemerahan, sedangkan fiksator tawas cenderung berwarna coklat muda. 
3. Hasil pewarnaan kain batik dengan ekstrak daun mangrove

Hasil warna yang ditimbulkan menggunakan bagian daun mangrove dengan fiksator tunjung cenderung berwarna abu-abu kehijauan, dengan fiksator kapur cenderung berwarna pink, sedangkan fiksator tawas cenderung berwarna coklat muda.

4. Hasil pewarnaan kain batik dengan ekstrak buah mangrove

Hasil warna yang ditimbulkan menggunakan bagian buah mangrove dengan fiksator tunjung cenderung berwarna abu-abu kehijauan, dengan fiksator kapur cenderung berwarna coklat muda, sedangkan fiksator tawas cenderung berwarna coklat muda.

\section{KESIMPULAN DAN SARAN}

\subsection{Kesimpulan}

Berdasarkan penelitian yang telah dilakukan maka didapatkan kesimpulan bahwa dari setiap ekstraksi 4 bagian dari mangrove yaitu kulit batang, akar, daun, dan buah menghasilkan warna yang berbeda-beda begitu juga setelah proses fiksasi. Ketika dilakukan fiksasi dengan tunjung warna berubah abu-abu, fiksasi dengan kapur mengarah ke warna pink/jingga, fiksasi dengan tawas menghasilkan warna jingga.

\subsection{Saran}

Berdasarkan hasil yang diperoleh dalam penelitian, maka ada beberapa saran yang dapat diberikan, yaitu:

1. Perlu penelitian lebih lanjut untuk analisis ketahanan luntur terhadap cahaya, panas penyetrikaan, dan keringat.

2. Perlu penelitian lebih lanjut untuk proses dengan mordanting.

\section{DAFTAR PUSTAKA}

Kurniawati, Eny, 2015. Batik Mangrove Rungkut Surabaya. Universitas Negeri Surabaya. Surabaya.

Pujilestari, T. 2015. Review : Sumber dan Pemanfaatan Zat Warna Alam untuk Keperluan Industri. Jurnal Dinamika Kerajinan dan Batik, Vol. 32 (2) : 93-106. Yogyakarta: Balai Besar Kerajinan dan Batik.

Rini, S., Dkk. 2011. Pesona Warna Alami Indonesia, Jakarta : Yayasan Keanekaragaman Hayati Indonesia.

Samsi, S. S. 2011. Teknik dan Ragam Hias Batik Solo \& Yogyakarta. Yogyakarta: Yayasan Titian Masa Depan (Titian Foundation).

Soesanto, S. K. S. 1980. Seni Kerajinan Batik Indonesia, Yogyakarta : Balai Penelitian Batik dan Kerajinan, Lembaga Penelitian dan Pendidikan Industri, Departemen Perindustrian R.I.

Sardjono. 2010. Teknologi Pewarnaan Batik Zat Warna Alam. Yogyakarta: Balai Besar Kerajinan dan Batik. 